\title{
Exergy Models and Tar Removal Techniques in Biomass Gasification
}

\author{
Ahsan Ayub $^{1}$ and Uzair Ibrahim ${ }^{2}$ * \\ ${ }^{1}$ US. Pakistan Center for Advanced Studies in Energy, National University of Sciences and Technology, \\ Islamabad, Pakistan \\ ${ }^{2}$ Dept. of Chemical and Material Engineering, National University of Sciences and Technology, Islamabad, \\ Pakistan
}

*Corresponding Author email: ibrahimuzair@ymail.com

Article History

Received: 15 July 2018

Accepted: 13 September 2018

Published: 01 October 2018

Student(s)

- Uzair Ibrahim

Academic Year: 2017-18

Course Level: Bachelor

Course Name: Chemical Engineering

Course year: $4^{\text {th }}$ year $/ 8^{\text {th }}$ Semester

Mentor(s)

- Ahsan Ayub

\section{ABSTRACT}

Quest for higher conversion efficiency and reduced environmental impact has increased the focus on renewable energy sources. Biomass is a sustainable form of energy that can be used as an alternate of fossil fuels through biomass gasification. Gasification is one of the most used methods for converting biomass into syngas that is a usable form of energy. The biomass gasification serves as a promising process for energy production. However, uncertainty in process variables and formation of tar has been a challenge in efficient process design and operation. This paper contains literature review of different models used for gasification, tar removal techniques along with Fischer Tropsch reactions for conversion of biomass to liquid fuels. The paper shows circulating and bubbling fluidized bed gasifier as the most efficient model for tar removal and greater exergy efficiency.

Keyword: Gasification, Biomass, Tar removal, Fischer Tropsch reaction, Exergy mode

\section{Introduction}

Biomass based energy generation system has been used since 18th century. Biomass is getting higher importance due to its renewable nature and reduced greenhouse effect. However, it cannot completely replace fossil fuels, but according to the World Energy Assessment report, around 9.5\% of world's energy requirements are fulfilled by biomass [1]. Biomass is a renewable plant-based material that includes woody crops, herbaceous biomass, and agricultural remains. Biomass gasification is a thermochemical process for converting this solid mass into gaseous fuel termed as syngas [2]. The syngas is a mixture of carbon monoxide, hydrogen methane and carbon dioxide along with some amount of ethane and propane. Sulphuric acid and hydrochloridric acid or inert gases, such as nitrogen, can also be present as impurities in the syngas. The concentration of these impurities depends on properties of biomass and gasification process. The produced gas has a lowest heating value (LHV) of 4 to $13 \mathrm{MJ} / \mathrm{Nm}^{3}[3,4]$.

With syngas, solid residue is also produced termed as tar. Tar formation is a main problem encountered in biomass gasification. At lower temperatures, condensed tar results in blocking and fouling of equipment. Therefore, it is important to remove tar from the process to achieve higher conversion efficiency. The technologies used for this purpose includes primary (treatments inside the gasifier) and secondary methods (hot gas cleaning after the gasifier). Although secondary methods are more effective than primary ones [1]. 
Biomass gasification is an endothermic process that comprises of four step: oxidation, drying, pyrolysis and reduction. In oxidation, oxygen supply is limited to oxidize only a fraction of biomass to generate energy for endothermic reactions. This results in production of carbon monoxide, carbon dioxide and water. Later, the feed is dried to remove moisture from biomass. Complete moisture removal is achieved at $150^{\circ} \mathrm{C}$ temperature [5]. This is followed by pyrolysis in which carbonaceous biomass is decomposed into light weight molecules. Tar formation takes places during this step. In reduction, all the products from oxidation and pyrolysis reacts together to form syngas [6,7]. There have been several concerns related to biomassbased power generation, like environmental impact and conversion efficiency, but due to depleting fossil fuel reserves the use of biomass is still a valid option. Fluidized gasifier is one of the most commonly used gasifier for the production of syngas from Biomass [8,9]. In order to realize efficient design of the biomass gasification, computational methods for modeling and thermodynamic process have been the focus of research. The objective of this study is to review the existing models for biomass gasification, techniques that can be used for tar removal, and potential of the process for hydrogen production.

\section{Power Generation}

Bridgwater (1994) focused his work on the power generation by using gasification of biomass from most developed techniques along with the economic analysis of electricity generation [38]. Thomsen et al. (2011) studied the biomass gasification possibility of cogeneration. They also discussed the most stable biomass gasification state [17]. Asadullah (2013) reviewed the problems associated with power generation technique in biomass gasification process [16]. The study highlighted the problems mainly associated with biomass pretreatment and syngas production [21].

\section{Biomass Gasification Models}

Fletcher et al. (1999) worked on the combustion of biomass by using CFD as tool. They worked on separate thermodynamics model for different zones of gasifier and designed model for all of these steps by using CFX4 and CFD [15]. Gil et al. (1999) worked on gasifier of biomass gasification using bubbling fluidized and atmospheric bed $[19,15]$. In this study, three most prominent variables were studied for the gasifier including Air, Oxygen and steam mixture, Pure steam. Franco et al. (2002) reduced the effect of diluting nitrogen by using steam gasification of biomass. The process omitted the need of oxygen plant making it highly cost effective and produced high energy gas [10]. The experimental model proposed by Franco et al. (2002) is shown in Fig.1.

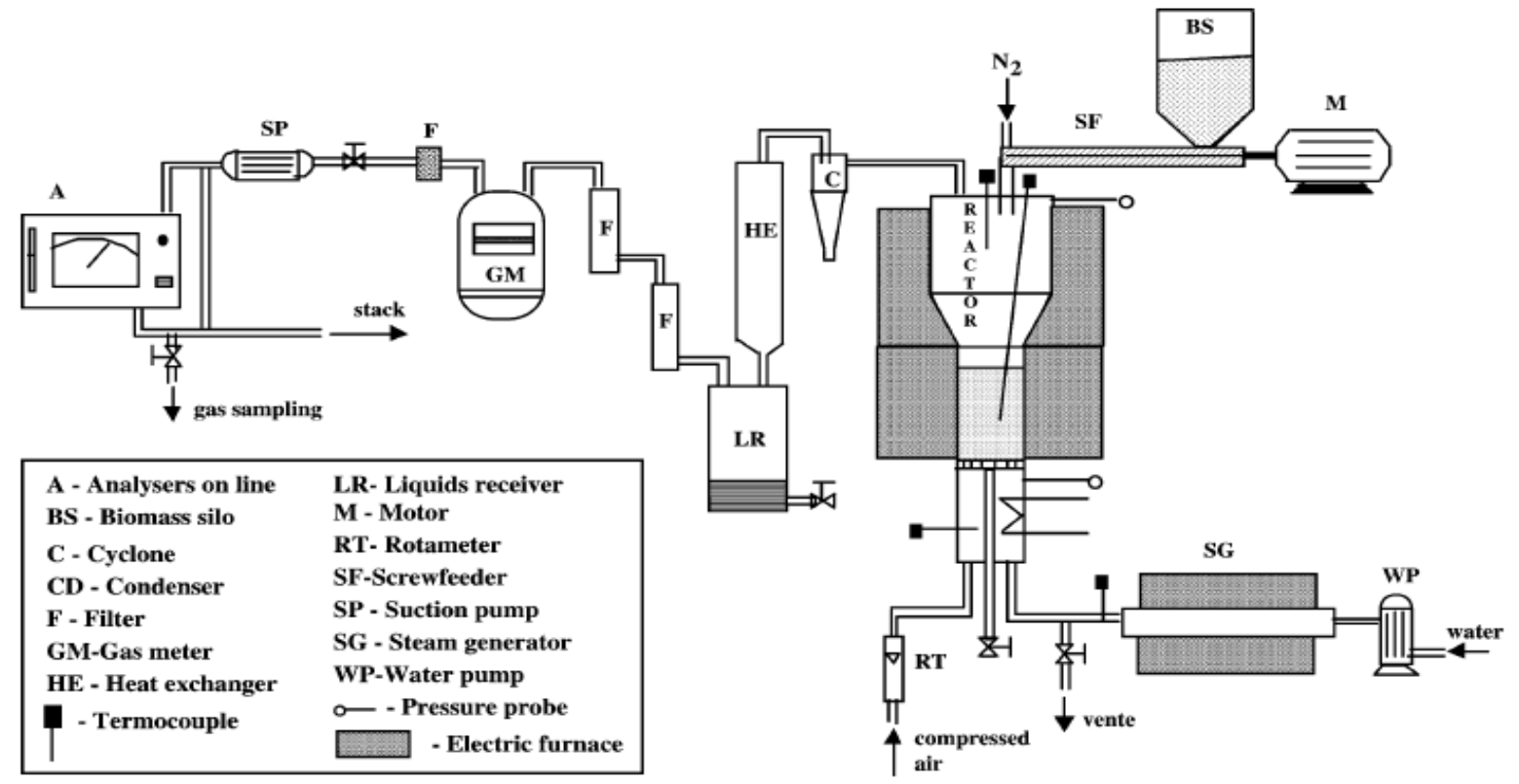

Figure 1: schematic diagram of process installation [10] 
Ayub et al., Adv. J. Grad. Res.; Vol. 5, Issue 1, pp: 16-23, January 2019

Matsumura et al. (2003) worked on the pretreatment of biomass by making slurry of biomass at temperature range of $1500 \mathrm{C}-200 \mathrm{OC}$. In this study super critical fluidized bed reactor is designed to investigate the behavior and feasibility of solid biomass for hydrogen production [33]. Barea et al. (2010) worked on the reactor modelling for solid fuels gasification like waste materials and biomass gasification. Circulating and bubbling fluidized bed reactor are modelled due to model simplicity, thus avoiding uncertainty of complex problems. To represent the fluid dynamics, semi-empirical correlation was modelled in comprehensive fluidized models. CFD is also used as tool for the modelling of biomass gasification due to increasing demand of the tool [11]. Fluidized Bed Biomass Gasification (FBBG) process description is as shown in Fig.2.

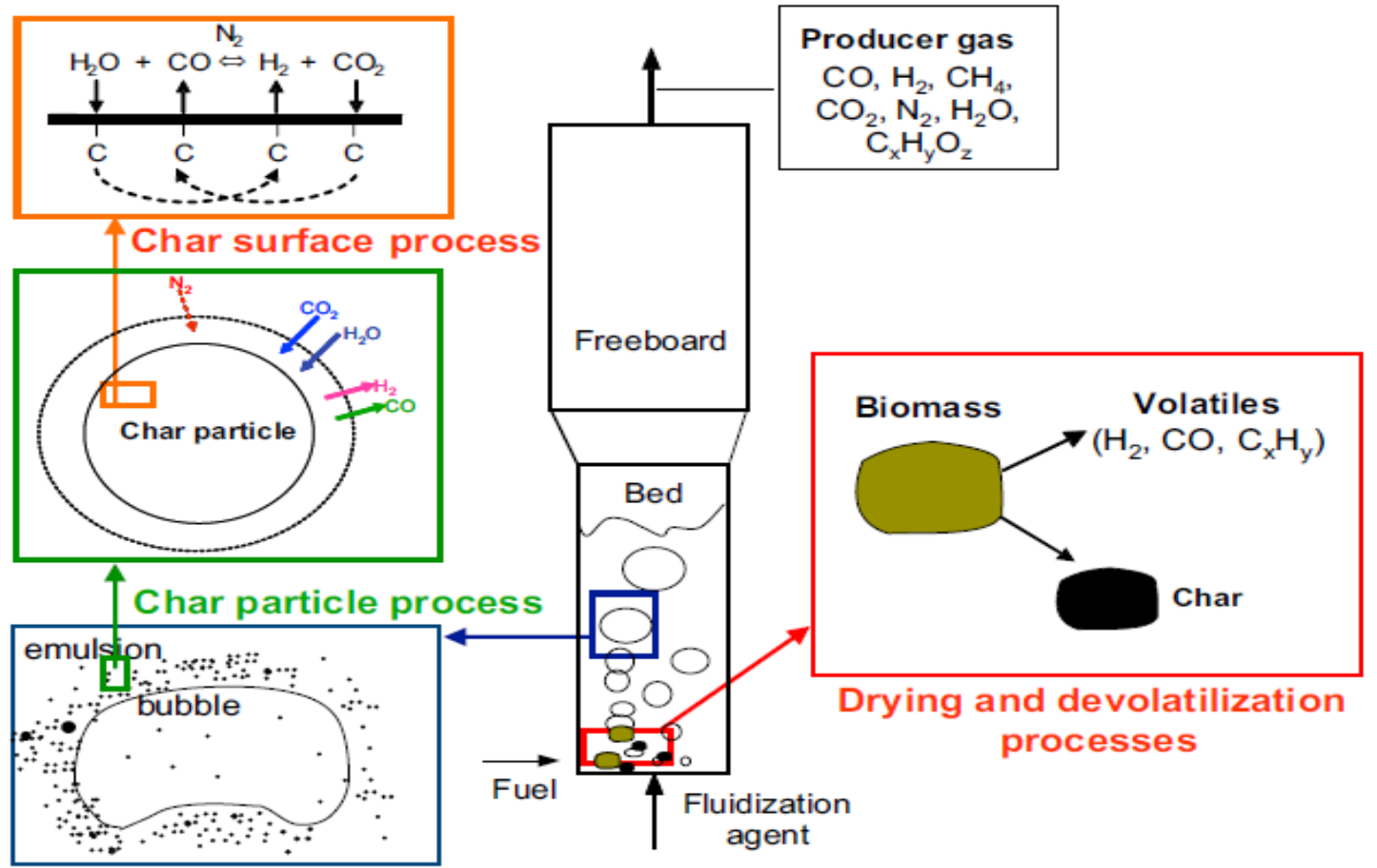

Point-scale of reactor process

Figure 2: Process description of FBBG (Fluidized Bed Biomass Gasification) [11]

Work of Meng et al. (2011) is focused on conversion efficiency of gasifier by using different fuels like, willow (woody biomass), agrol (wood pallets made up of sawdust and timber) and DDGS (Dry Distiller`s Grains with Solubles) [18]. Couto et al. (2013) worked on final composition of syngas by studying the effect of different operational parameters including reactor type, temperature conditions, pressure and the moisture involve in biomass [34]. Ku et al. (2014) studied the biomass gasification in fluidized bed reactor by using CFD-DEM model that can described thermal, dense and reactive multi-phase flows [23]. This model includes:

- The Eulerian-langrangian concept for the representation of gas transport equation and particle governing equation.

- Modeling of heterogeneous and homogeneous reactions.

- By k-e model turbulence was resolved.

- Soft sphere collision model to resolve sand particles and wall collisions.

- In simulation model continuous biomass injection is favored.

\section{Tar Removal Techniques:}

Devi et al. (2002) studied different methods for tar removal in biomass gasification [1]. All these methods can be categorized in two types as follows: 
- Primary method where tar is removed in gasifier as shown in Fig.3

- Secondary method where tar is removed outside the gasifier as shown in Fig.4

Han et al. (2006) reviewed the literature for tar removal in biomass gasification process. They divided tar removal technologies in to five groups including cyclone, filters, granular beds, RPS, and electrostatic precipitator [37]. Śंwierczyniski et al. (2007) studied the efficiency of Ni/Olivine as catalyst in tar removal. Catalyst efficiency was tested at different operation parameters and also the deactivation of catalyst by deposition of carbon in gasifier was determined.

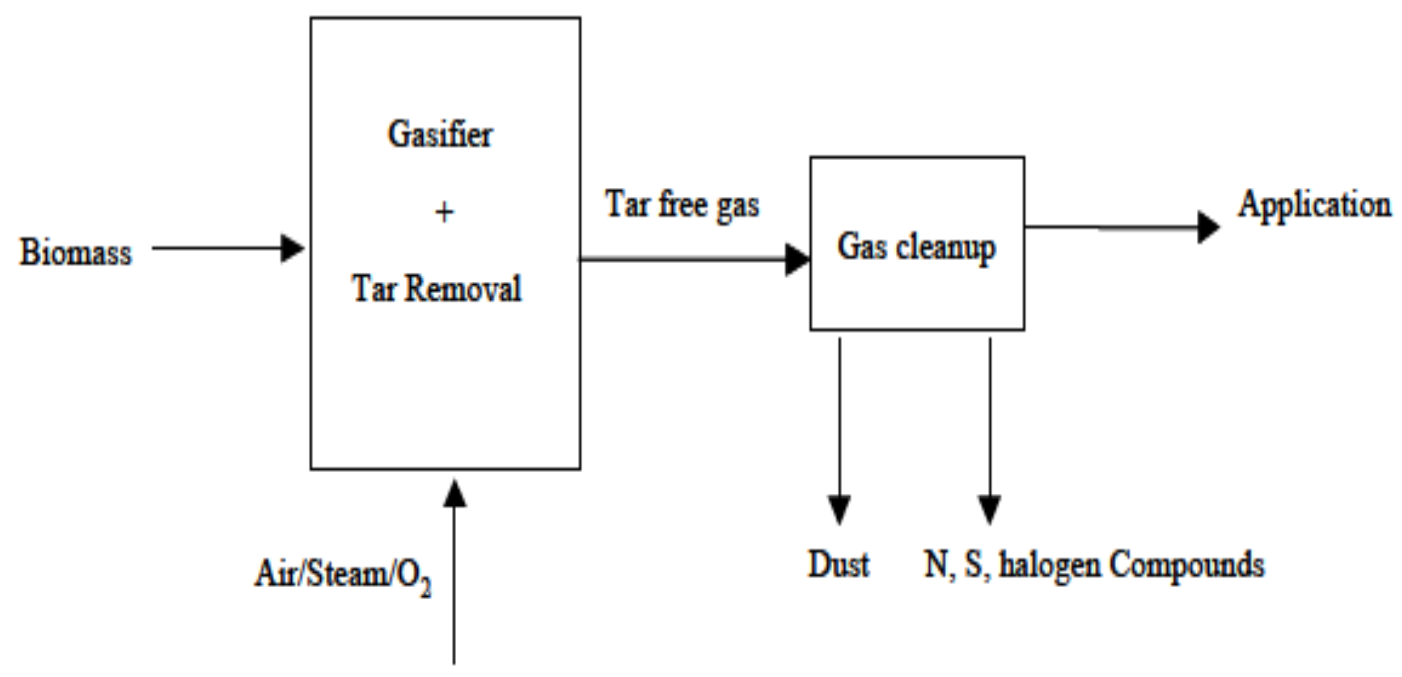

Figure 3: Primary method of tar removal [1]

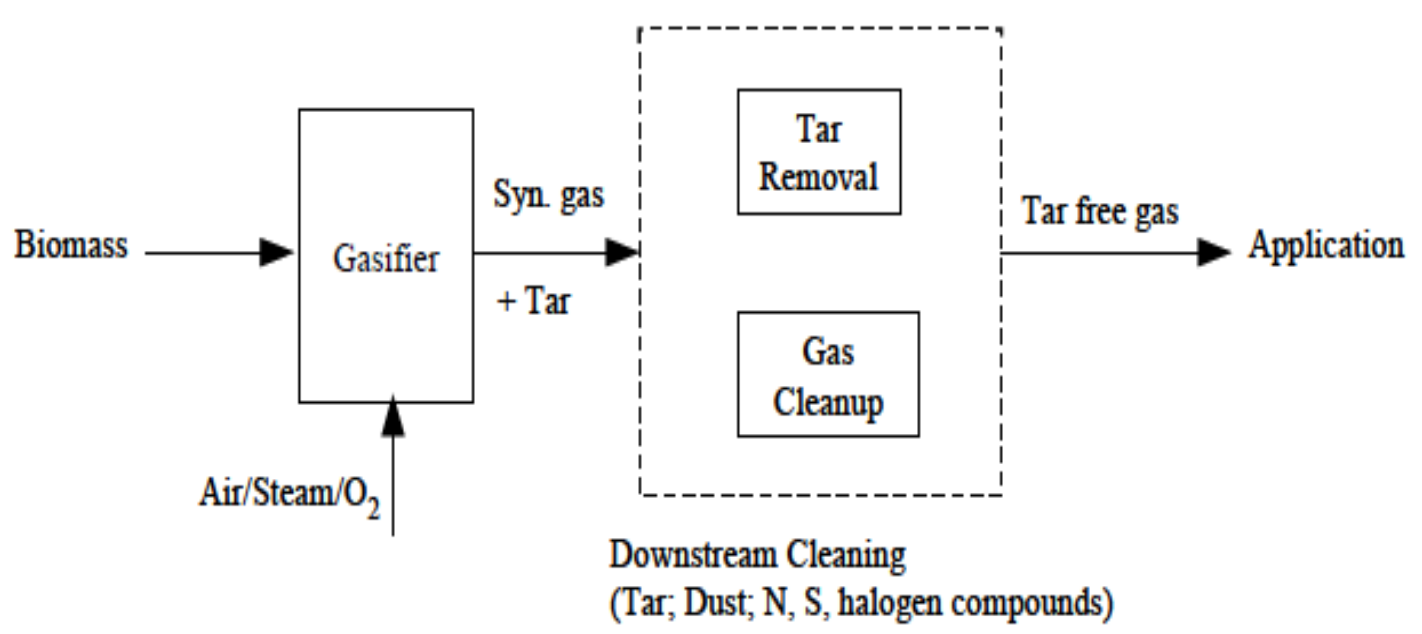

Figure 4: Secondary method of tar removal [1]

Virginie et al. (2010) studied the Fe/olivine catalyst for tar removal and also the behavior of catalyst with steam methane reforming. Different characterization techniques were employed to understand physicochemical behavior of catalyst [39]. Cao et al. (2005) proposed the tar free novel gasification process by using air as shown in Fig.5. The tar produced in biomass gasifier was decomposed by adding secondary air and fuel gas. Experiment were performed to quantify the operating parameters effecting LHV (low heating value) and carbon conversion efficiency in testing facility of lab [12]. 
Ayub et al., Adv. J. Grad. Res.; Vol. 5, Issue 1, pp: 16-23, January 2019

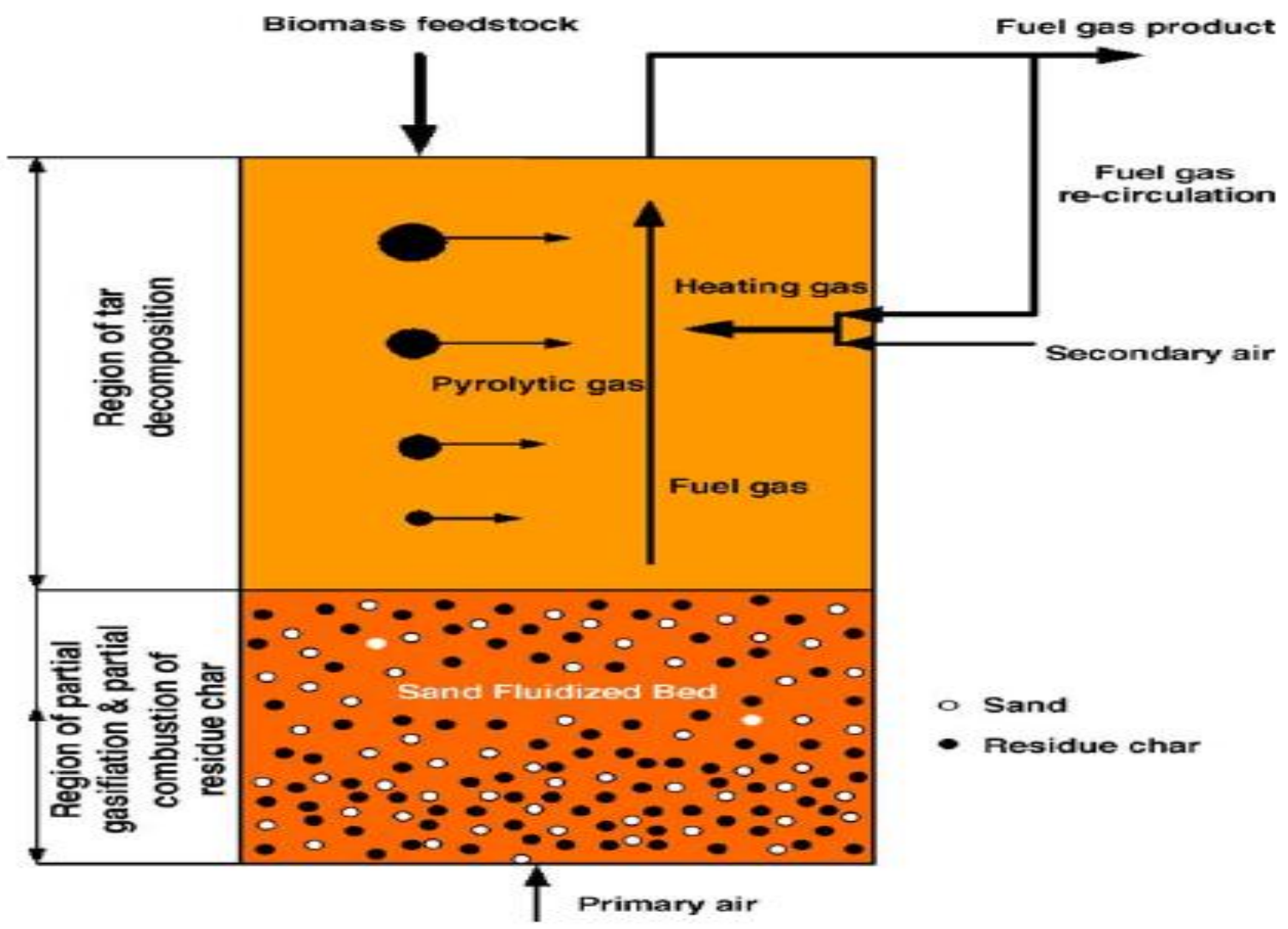

Figure 5: The concept schematic of novel gasifier [12]

Zhao et al. (2014) worked on the ceramic processing method for the preparation of olivine supported $\mathrm{Ni}_{2} \mathrm{SiO}_{4}$ catalyst for the tar removal in biomass gasification. Methane steam reforming is used as reaction model along with water gas shift and $\mathrm{CO}_{2}$ dry reforming reactions [24].

\section{Biomass to Liquid Fuel}

Tijmensen et al. (2002) worked on the evaluation of different Fischer Tropsch production techniques from biomass gasification [13]. They worked on the following parameters:

- Economics and technical feasibility of Fischer Tropsch reaction [25].

- Most favorable system for biomass cogeneration with Fischer Tropsch concept [32].

The block diagram of Biomass to Fischer Tropsch liquid shown in Fig.6

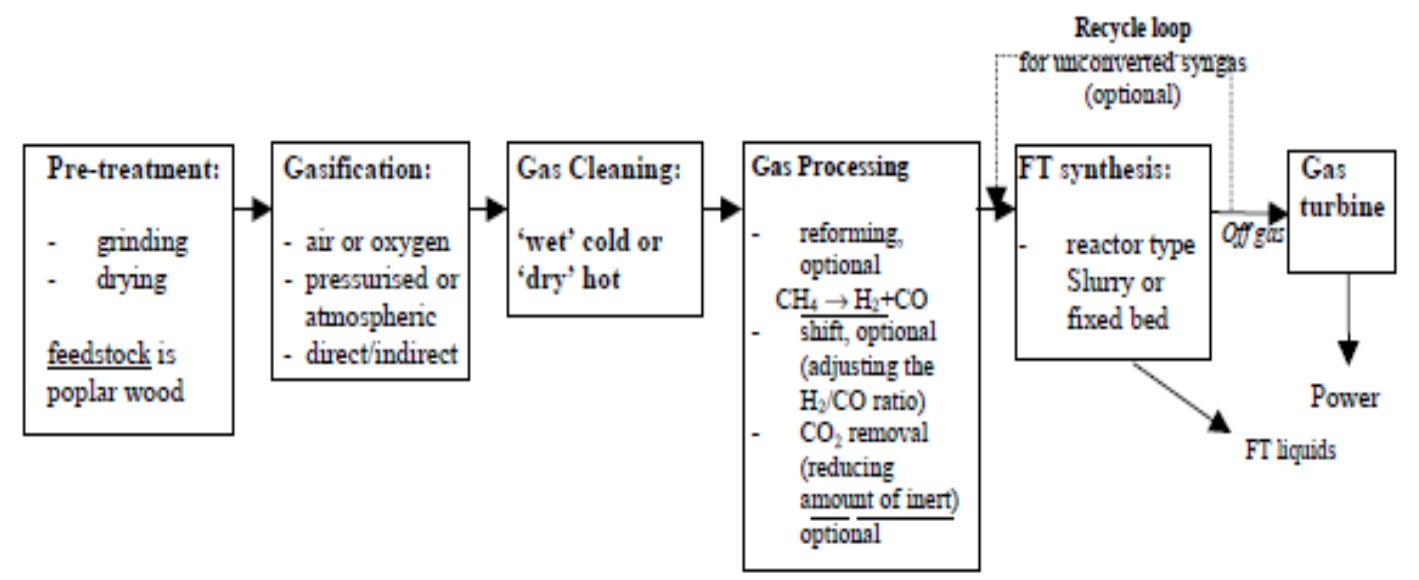

Figure 6: Schematic of conversion of Biomass to Fischer Tropsch liquid [13] 
Exergy Models and Tar Removal Techniques in Biomass Gasification

Ail et al. (2016) discusses the technicality of FT reaction and present the novelty of biomass to liquid (BTL) fuel via FT. They also worked on the chemistry of FT, catalyst involved in reactions, kinetics of reaction, factors responsible for separation of products and the most important one economics [22]. Later, Ail et al. (2017) worked on the economic feasibility of biomass gasification plant cogenerated with low temperature FT reactor. The biomass gasification was carried out in fixed bed, oxy-steam gasification system [20, 22].

\section{Energy and Exergy Models}

Ptasinski et al. (2005) worked on evaluation of exergtic efficiencies of biomass gasification. They used model of different authors to study the optimal operating conditions for maximum efficiency. In this paper gasification efficiencies were compared for different fuels [28, 29]. Toonssen et al. (2008) worked is related to enhance the efficiency of the gasification process while considering five different types of gasification techniques. These five techniques improve the hydrogen production up to $99.99 \%$. These models have two different operating conditions low temperature and high temperature. The study used a computer program, cycle-tempo, to model the system for thermodynamic evaluation of gasification [31]. Karamarkovic et al. (2009) worked on the energy analysis by varying the feedstock sensible heat as sensible heat plays major role in energy efficiency of gasification. For energy efficiency, the moisture content has a great effect on biomass gasification [27]. Abuadala et al. (2009) studied the effect of different parameters with and without experiments on gasification. This study basically discussed the factors effecting the hydrogen production from biomass in self-heated gasifier [30]. Abuadala et al. (2010) proposed gasifier model that quantifies the effects of steam-biomass ratio and temperature on the exergy and energy efficiencies. This model helps in improving the exergy and energy efficiency of hydrogen production from biomass gasification [26]. Panopoulos et al. (2005) worked on exergtic analysis of SOFC-CHP system by using the novel gasification of allothermal steam gasification [14]. Flow sheet for SOFC are shown in Fig.7.

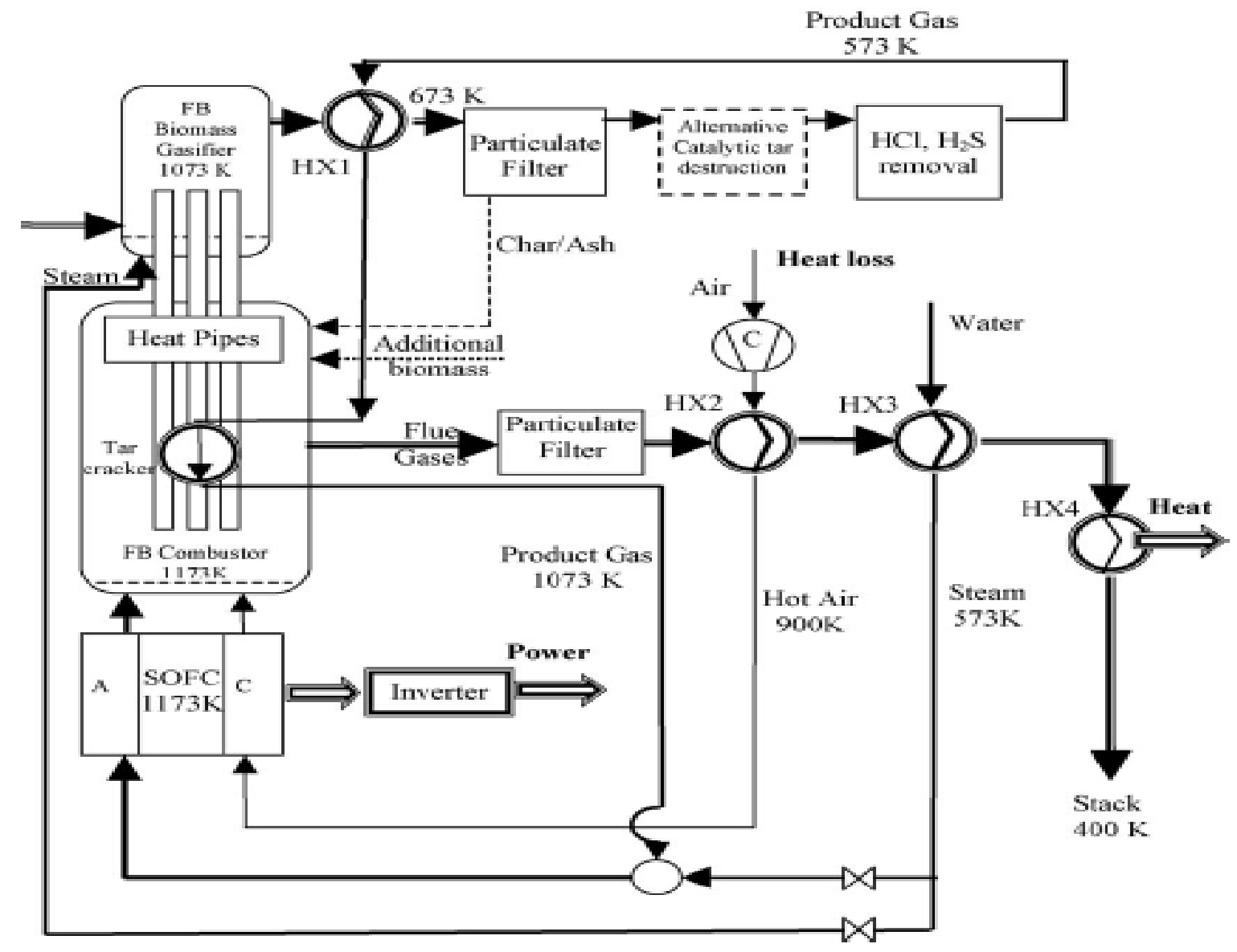

Figure 7: Flow sheet of all thermal steam gasification [14] 
Ayub et al., Adv. J. Grad. Res.; Vol. 5, Issue 1, pp: 16-23, January 2019

Vitasari et al. (2010) worked on exergy efficiency and proposed the novel methods to improve the biomass indirect gasification. The main parameters which are responsible for the exergy efficiency is gasifier pressure and methanation reactor temperature also known as cooled reactor temperature [29]. Mehdi et al. (2012) study the effect of biomass moisture and gasification medium by energy and exergy analysis. Investigation was performed for process behavior by varying two feed conditions and to evaluate the energy efficiency $[35,36]$.

\section{Conclusion}

Biomass can be converted into a clean-burning gaseous fuel by gasification that can be a great alternative of fossil fuel with low $\mathrm{CO}_{2}$ emissions. Gasification process has a great potential to produce fuel and chemicals. The study throws light on different model proposed for efficient working of gasification system and technologies devised to reduce the production and to enhance the removal of tar. Among different models, circulating and bubbling fluidized bed gasifier is the most efficient one with greater exergy efficiency. Moreover, Fischer Tropsch reactions have significance in conversion of biomass into liquid fuel that serves as a renewable source of energy.

\section{How to Cite this Article}

A. Ayub and U. Ibrahim, "Exergy Models and Tar Removal Techniques in Biomass Gasification", Adv. J. Grad. Res., vol. 5, no. 1, pp. 16-23, Oct. 2018. Doi: 10.21467/ajgr.5.1.16-23

\section{References}

[1] L. Devi, K. J. Ptasinski, and F. J. J. G. Janssen, "A review of the primary measures for tar elimination in biomass gasification processes," Biomass and Bioenergy 2003, vol. 24, no. 2, pp. 125-140.

[2] S. Rapagnà, N. Jand, A. Kiennemann, and P. U. Foscolo, "Steam-gasification of biomass in a fluidised-bed of olivine particles," Biomass and Bioenergy 2000, vol. 19, no. 3, pp. 187-197.

[3] K. Qian et al., "Effects of Biomass Feedstocks and Gasification Conditions on the Physiochemical Properties of Char," Energies 2013, vol. 6, no. 8, pp. 3972-3986.

[4] Y. Wu, W. Yang, and W. Blasiak, "Energy and Exergy Analysis of High Temperature Agent Gasification of Biomass," Energies 2014, vol. 7, no. 4, pp. 2107-2122.

[5] C. N. Hamelinck, A. P. C. Faaij, H. den Uil, and H. Boerrigter, "Production of FT transportation fuels from biomass; technical options, process analysis and optimisation, and development potential," Energy 2004, vol. 29, no. 11, pp. 1743-1771.

[6] P. McKendry, "Energy production from biomass (part 1): overview of biomass," Bioresource Technology 2002, vol. 83, no. 1, pp. $37-46$.

[7] P. McKendry, "Energy production from biomass (part 3): gasification technologies," Bioresource Technology 2002, vol. 83, no. 1, pp. 55-63.

[8] J. Corella, A. Orío, and P. Aznar, "Biomass Gasification with Air in Fluidized Bed: Reforming of the Gas Composition with Commercial Steam Reforming Catalysts," Ind. Eng. Chem. Res. 1998, vol. 37, no. 12, pp. 4617-4624.

[9] A. Ergudenler and A. E. Ghaly, "Quality of gas produced from wheat straw in a dual-distributor type fluidized bed gasifier," Biomass and Bioenergy 1992, vol. 3, no. 6, pp. 419-430.

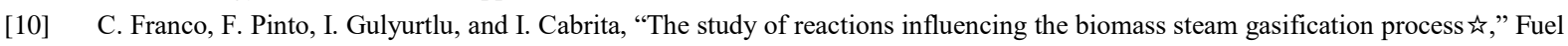
2003, vol. 82, no. 7, pp. 835-842.

[11] A. Gómez-Barea and B. Leckner, "Modeling of biomass gasification in fluidized bed," Progress in Energy and Combustion Science 2010, vol. 36, no. 4, pp. 444-509.

[12] Y. Cao, Y. Wang, J. T. Riley, and W.-P. Pan, "A novel biomass air gasification process for producing tar-free higher heating value fuel gas," Fuel Processing Technology 2006, vol. 87, no. 4, pp. 343-353.

[13] M. J. A. Tijmensen, A. P. C. Faaij, C. N. Hamelinck, and M. R. M. van Hardeveld, "Exploration of the possibilities for production of Fischer Tropsch liquids and power via biomass gasification," Biomass and Bioenergy 2002, vol. 23, no. 2, pp. 129-152.

[14] K. D. Panopoulos, L. Fryda, J. Karl, S. Poulou, and E. Kakaras, "High temperature solid oxide fuel cell integrated with novel allothermal biomass gasification: Part II: Exergy analysis," Journal of Power Sources 2006, vol. 159, no. 1, pp. 586-594.

[15] D. F. Fletcher, B. S. Haynes, F. C. Christo, and S. D. Joseph, "A CFD based combustion model of an entrained flow biomass gasifier," Applied Mathematical Modelling 2000, vol. 24, no. 3, pp. 165-182.

[16] M. Asadullah, "Barriers of commercial power generation using biomass gasification gas: A review," Renewable and Sustainable Energy Reviews 2014, vol. 29, pp. 201-215.

[17] J. Ahrenfeldt, T. P. Thomsen, U. Henriksen, and L. R. Clausen, "Biomass gasification cogeneration - A review of state of the art technology and near future perspectives," Applied Thermal Engineering 2013, vol. 50, no. 2, pp. 1407-1417.

[18] X. Meng, W. de Jong, N. Fu, and A. H. M. Verkooijen, "Biomass gasification in a $100 \mathrm{kWth}$ steam-oxygen blown circulating fluidized bed gasifier: Effects of operational conditions on product gas distribution and tar formation," Biomass and Bioenergy 2011, vol. 35, no. 7, pp. 2910-2924.

[19] J. Gil, J. Corella, M. P. Aznar, and M. A. Caballero, "Biomass gasification in atmospheric and bubbling fluidized bed: Effect of the type of gasifying agent on the product distribution," Biomass and Bioenergy 1999, vol. 17, no. 5, pp. 389-403. 
[20] J. Corella, A. Orío, and P. Aznar, "Biomass Gasification with Air in Fluidized Bed: Reforming of the Gas Composition with Commercial Steam Reforming Catalysts," Ind. Eng. Chem. Res. 1998, vol. 37, no. 12, pp. 4617-4624.

[21] M. J. Antal, "Biomass Pyrolysis: A Review of the Literature Part 2-Lignocellulose Pyrolysis," in Advances in Solar Energy, Springer, Boston, MA, 1985, pp. 175-255.

[22] S. S. Ail and S. Dasappa, "Biomass to liquid transportation fuel via Fischer Tropsch synthesis - Technology review and current scenario," Renewable and Sustainable Energy Reviews 2016, vol. 58, pp. 267-286.

[23] X. Ku, T. Li, and T. Løvås, "CFD-DEM simulation of biomass gasification with steam in a fluidized bed reactor," Chemical Engineering Science 2015, vol. 122, pp. 270-283.

[24] Z. Zhao et al., "Characterization of olivine-supported nickel silicate as potential catalysts for tar removal from biomass gasification," Applied Catalysis A: General 2015, vol. 489, pp. 42-50.

[25] M. A. Caballero, M. P. Aznar, J. Gil, J. A. Martín, E. Francés, and J. Corella, “Commercial Steam Reforming Catalysts To Improve Biomass Gasification with Steam-Oxygen Mixtures. 1. Hot Gas Upgrading by the Catalytic Reactor,” Ind. Eng. Chem. Res. 1997, vol. 36, no. 12, pp. 5227-5239.

[26] A. Abuadala and I. Dincer, "Efficiency evaluation of dry hydrogen production from biomass gasification," Thermochimica Acta 2010, vol. 507-508, pp. 127-134.

[27] R. Karamarkovic and V. Karamarkovic, "Energy and exergy analysis of biomass gasification at different temperatures," Energy 2010, vol. 35 , no. 2, pp. 537-549.

[28] K. J. Ptasinski, M. J. Prins, and A. Pierik, "Exergetic evaluation of biomass gasification,” Energy 2007, vol. 32, no. 4, pp. $568-574$.

[29] C. R. Vitasari, M. Jurascik, and K. J. Ptasinski, "Exergy analysis of biomass-to-synthetic natural gas (SNG) process via indirect gasification of various biomass feedstock," Energy 2011, vol. 36, no. 6, pp. 3825-3837.

[30] A. Abuadala, I. Dincer, and G. F. Naterer, "Exergy analysis of hydrogen production from biomass gasification," International Journal of Hydrogen Energy 2010, vol. 35, no. 10, pp. 4981-4990.

[31] R. Toonssen, N. Woudstra, and A. H. Verkooijen "Exergy analysis of hydrogen production plants based on biomass gasification," International journal of hydrogen energy 2008, vol. 33, pp. 4074-82.

[32] A. S. Snehesh, H. S. Mukunda, S. Mahapatra, and S. Dasappa, "Fischer-Tropsch route for the conversion of biomass to liquid fuels Technical and economic analysis," Energy 2017, vol. 130, pp. 182-191.

[33] Y. Matsumura and T. Minowa, "Fundamental design of a continuous biomass gasification process using a supercritical water fluidized bed," International Journal of Hydrogen Energy 2004, vol. 29, no. 7, pp. 701-707.

[34] N. Couto, A. Rouboa, V. Silva, E. Monteiro, and K. Bouziane, "Influence of the Biomass Gasification Processes on the Final Composition of Syngas," Energy Procedia 2013, vol. 36, pp. 596-606.

[35] M. Hosseini, I. Dincer, and M. A. Rosen, "Steam and air fed biomass gasification: Comparisons based on energy and exergy," International Journal of Hydrogen Energy 2012, vol. 37, no. 21, pp. 16446-16452.

[36] D. Świerczyński, S. Libs, C. Courson, and A. Kiennemann, "Steam reforming of tar from a biomass gasification process over Ni/olivine catalyst using toluene as a model compound," Applied Catalysis B: Environmental 2007, vol. 74, no. 3, pp. 211-222.

[37] J. Han and H. Kim, "The reduction and control technology of tar during biomass gasification/pyrolysis: An overview," Renewable and Sustainable Energy Reviews 2008, vol. 12, no. 2, pp. 397-416.

[38] A. V. Bridgwater, "The technical and economic feasibility of biomass gasification for power generation," Fuel 1995, vol. 74, no. 5, pp. 631-653.

[39] M. Virginie, C. Courson, and A. Kiennemann, "Toluene steam reforming as tar model molecule produced during biomass gasification with an iron/olivine catalyst," Comptes Rendus Chimie 2010, vol. 13, no. 10, pp. 1319-1325.

Publish your research article in AIJR journals-

$\checkmark \quad$ Online Submission and Tracking

$\checkmark$ Peer-Reviewed

$\checkmark$ Rapid decision

$\checkmark \quad$ Immediate Publication after acceptance

$\checkmark \quad$ Articles freely available online

$\checkmark \quad$ Retain full copyright of your article.

Submit your article at journals.aijr.in

\section{Publish your books with AIJR publisher-}

$\checkmark$ Publish with ISBN and DOI.

$\checkmark$ Publish Thesis/Dissertation as Monograph.

$\checkmark$ Publish Book Monograph.

$\checkmark$ Publish Edited Volume/ Book.

$\checkmark \quad$ Publish Conference Proceedings

$\checkmark \quad$ Retain full copyright of your books.

Submit your manuscript at books.aijr.org 